UDC 621. 313.333-185. 3

\title{
一次巻線のコイル端起磁力の形状を考慮し たリニアインダクションマシンの解析
}

\begin{tabular}{|c|}
\hline 論 文 \\
\hline $54-\mathrm{B} 86$ \\
\hline
\end{tabular}

\author{
正 員 梅 津 長 徳 (宮崎犬) \\ 正員野 中 作太郎 (九州犬)
}

\section{1. まえがき}

先に筆者らは低速りニアインダクションマシン（低 速機)の特性 ${ }^{(1)}$ について，一次鉄心積み厚方向（横方 问）の起磁力分者は一様とした二次元空間高調波解析

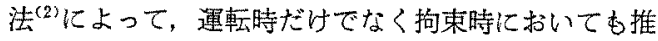
力，垂直力に端效果が生ずることを明らかにしたが， 二次元解析では，一次表面電流の進行磁界方向（莸方 向）成分は Russell-Norsworthy の係数によって補正 さ扎ている加，磁束密度の横方向成分を算出できない ため，一次鉄心表面住直に作用する力（以後重直力 之呼ふ引）や，一次表面に平行で二次導体板の幅方向， すなわち横方向に作用する力（以後横方向垂直力と呼 ふ）などを正しく把握することはできない。これら整 面力上横方向垂直力心，一次鉄心亡二次導体の支持案 内をするのに影響を及隹す重要なむのと考えられる。 しかし，現在まで横方向成分の磁束密度を考慮して， これらの力を検討した委のはないようである。これら 力の一つの解析法として，一次起磁力の緥方向分有之 横方向分布のそ机ぞれの形状を考慮した三次元解析法 がある。既に三次元解析として Oberretl 氏(3)や山村 氏ら (4)の報告があるが，いずれも横方向垂直力につい ては言及されていない。また垂值力では同氏の報告で 定電流運転時のものがあるが，定電生運転時までは言 及されていないようである。

一般に，一次巻線の形状には䉓甲形や小判形などが あるが，これら巻線の起磁力の横方向分布を原形のま まで解析することは困難であるので，本諭文では縦方 向上横力向に非常に長い一次鉄心を仮定し，一次巻線 による起磁力の值はできるだけ等価になり，しかす解 析に容易な横力向分布をむつ起磁力の形状として台形 分布を提案し，乙れ之一次起磁力口維方向分布は，従

Analysis of Linear Induction Machines Taking into Account Magnetomotive Force form Along the Coil End of the Prim. ary Winding. By Naganori Umezu, Member (Faculty of Engineering, Miyazaki University) \& Sakutaro Nonaka, Member (Faculty of Engineering, Kyushu University).

梅津套徳: 正員, 宮的大学工学部電気工学科

野中作太郎：正真，九州大学工学部䨋気工学科
来の二次元解析 ${ }^{(2)}$ を利用した三次元解析 (以後台形形 三次元解析と呼ふ）を行なった。との三次元解析上二 次元解析乞による速度特性の計算結果を比較して次の 事がらが認められた。すなわち推力の雨解析值の差異 は小さく，特に高速領域ではその差異は僅少となる。 垂直力の耐解析値の差巽の大きさは設計定数によって 異なり，特に高速機で顕著に表われる。京た二次導体

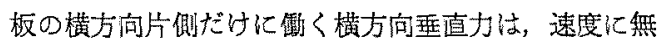
関係に反発力となることなどである゙。

以上のことから，推力の訐算仕徒来の二次元解析で もよく、リニアインダタションマシン(LIM)の支持案 内に影響を及济垂直力と，横方向垂声力の速度特性 を重点的に示した。

\section{2. 一次巻線のコイル端部起磁力の分布を 考慮した一次表面電流}

第 1 図に，一次巻線のコイル端部起磁力分布形状を 台形形としたa相起磁力の横方向分布 $f_{0}(y)$ を示す。 図加ら $f_{a}(y)$ は次式のフーリ工級数によって表示で きる。

$$
f_{a}(y)=N i_{a} \sum_{k=1}^{\infty} a_{k} \cos \frac{\pi}{h_{2 k}} y \quad(k=1,3,5, \cdots)
$$

但し $h_{2 k}=h_{2} / k$ : 横方向の第 $k$ 調波に対する等価半 波長 $(\mathrm{m}), h_{2}=$ 横方向基本波半波長 $(\mathrm{m})$ : 二次導体幅に 等しくとる。 $N: 1$ スロットあたりの一次巻線の替 数, $i_{a}: \mathrm{a}$ 相の潜線電流の瞬時值 $(\mathrm{A}), a_{k}=N i_{a}$ を単:

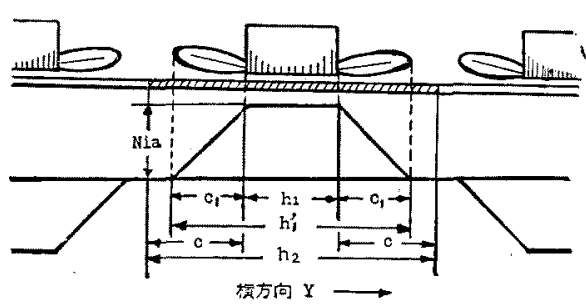

第 1 図 起磁力の横方向分布

Fig. 1. Mathematical model and m. m.f. distribution in the transverse direction. 
位アンベアターンとした䈔 $k$ 謂波の最大值：台形形の 場合は

$$
a_{k}=\frac{4}{\pi} \frac{1}{k c_{1}}\left(\frac{h_{2 k}}{\pi}\right)\left(\cos \frac{\pi}{h_{2 k}} \frac{h_{1}}{2}-\cos \frac{\pi}{h_{2 k}} \frac{h_{1}^{\prime}}{2}\right)
$$

但L, $h_{1}$ : 一次鉄心積厚 $(\mathrm{m}), h_{1}^{\prime}$ : 一次巻線横方向 幅 $(\mathrm{m}), c_{1}=\left(h_{1}{ }^{\prime}-h_{1}\right) / 2$ : 一次巻線オーバハング $(\mathrm{m})$

そこで，(2)式を用いた台形形三次元解析の一次起 磁力は，乙机上全く等価な起磁力を作る一次表面電流 $j_{1}=\left(j_{1 x}, j_{1 y}, 0\right)$ によって置換えることができる。そ こで，第2図（a)(b)LIM の解析モデルで，一次鉄 心之二次導体の配置と座標軸を示す。ことで，一次表 面電流の $x$ と $y$ の各成分 $j_{1 x}, j_{1 y}$ は連続である から次式が成立する。

$$
\nabla \cdot j_{1}=0: \frac{\partial j_{1 x}}{\partial x}+\frac{\partial j_{1 y}}{\partial y}=0
$$

$j_{1 x}$ 之 $j_{1 y}$ の $x$ 方向分布の第 $n$ 調波分之 $y$ 方向 分布の第 $k$ 調波分の表面電流 $j_{1 x, n k}, j_{1 y, n k}$ は，前進 波表面電流 $j_{1 x, f, n k}, j_{1 y, f, n k}$ と後進波表面電流 $j_{1 x}$, $b, n k, j_{1 y, b, n k}$ の和上して次式の複菜数で表示される。

$$
\begin{aligned}
& j_{1 x}=\sum_{n=1}^{\infty} \sum_{k=1}^{\infty}\left(j_{1 x, f, n k} \pm j_{1 x, b, n k}\right) \\
& j_{1 y}=\sum_{n=1}^{\infty} \sum_{k=1}^{\infty}\left(j_{1 y, f, n k} \pm j_{1 y, b, n k}\right)
\end{aligned}
$$

但し + : 偶数極, 一：奇数極, $n, k$ : いずれ屯 奇数値。そこで, $j_{1 y, f, n k}$

$$
\begin{aligned}
& j_{1 y, f, n k}=J_{1 f, n k} \cos \frac{\pi}{h_{2 k}} y \cdot e^{j \frac{\pi}{\tau_{1 n}}\left(v_{1 n} t-x\right)} \\
& J_{1 f, n k}=\sqrt{2} m \frac{k_{\omega n} k_{L p n} N_{p h}}{L_{1}} I_{1} k_{m f n} a_{k}
\end{aligned}
$$

但し， $\tau_{1 n}=L_{1} / n$ : 第 $n$ 調波沉対する $x$ 方向の等 価ポールピッチ $(\mathrm{m}), 2 L_{1}$ : 起磁力の紸方向基本波波 長 $(\mathrm{m}), v_{1 n}=2 \tau_{1 n} f_{1}$ ：第 $n$ 調波の移動速度 $(\mathrm{m} / \mathrm{s})$, $f_{1}$ : 電源周波数 $(\mathrm{Hz}) ， \quad J_{1 f, n k}$ : 一次表面電流前進波の 第 $n, k$ 調波の最大値 $(\mathrm{A} / \mathrm{m}) ， I_{1}: 1$ 相の電流実效值 (A) $, m:$ 相数, $N_{p h}=1$ 相の直列巻数 $=2 p q N, q$ : 毎極毎相のスロット数, $p$ : 片侧の極数, $k_{\bullet n}$ : 第 $n$ 調波の巻線係数, $k_{L p n}$ : 第 $n$ 調波の極係数, $k_{m f_{n}}$ : 前進波の第 $n$ 調波の相㐿数

また，後進波 $j_{1 y, b, n k}$ 恃(6)式で， $J_{1 f, n k} \rightarrow J_{1 b, n k}$, $\left(v_{1 n} t-x\right) \rightarrow\left(v_{1 n} t+x\right)$ 乙置換して得られる。とこで, $J_{1 b, n k}$ は (7)式て $k_{m f n} \rightarrow k_{m b n}=$ 後進波の第 $n$ 調波の 相係数汇置换して得られる。そてで, $j_{1 x, f, n k}$ は $j_{1 y}$, $f, a k$ との連続の条件式 (3) 式から次式で与えられる。

$$
j_{1 x, f, n k}=j \frac{\tau_{1 n}}{\pi} J_{1 f, n k} \frac{\pi}{h_{2 k}} \sin \frac{\pi}{h_{2 k}} y
$$

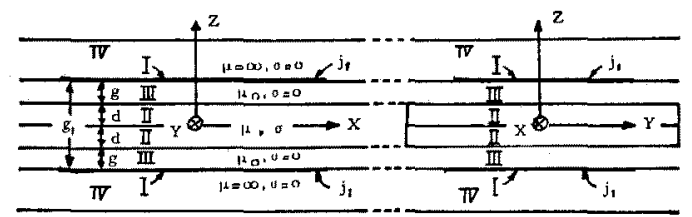

(a)

(b)

第 2 㘝りニアインダクションマシンの解析モデル Fig. 2. Analytical model of the linear induction machine.

$$
\times e^{j \frac{\pi}{\tau_{1 n}}\left(\eta_{1 n} t-x\right)}
$$

徯進波 $j_{1, n, b, \pi k}$ は(8)式で $j \rightarrow-j, J_{1 f, n k \rightarrow J_{1 b, n k}}$ $\left(v_{1 n} t-x\right) \rightarrow\left(v_{1 n} t+x\right)$ 之置換して得られる。

\section{3. 一次表面電流による三次元解析}

〈3.1〉エアギャップ磁束密度本論文の解析の 対象として，両側式リニアインダクションマシンを用 いる。

第 2 図（a），(b) で前進波一次表面電流， $j_{1, r, n k}$ $=\left(j_{1 x, f, n k}, j_{1 y, f, n k}, 0\right)$ 飞対する各領域の磁束密度

$\boldsymbol{B}_{f, n k}=\left(B_{x, f, n k}, B_{y, f, n k}, B_{z, f, n k}\right)$ はベクトルポテン シャル $\boldsymbol{A}_{f, n k}=\left(A_{x, f, n k}, A_{y, f, n k}, 0\right)$ にっって求められ る。そこで，次式で示す電磁方程式が得られる。

$$
\nabla^{2} \boldsymbol{A}_{f, n k}=\sigma \mu\left\{\frac{\partial \boldsymbol{A}_{f, n k}}{\partial t}-\boldsymbol{v} \times\left(\nabla \times \boldsymbol{A}_{f, n k}\right)\right\}
$$

$$
\begin{aligned}
& \boldsymbol{B}_{f, n k}=\nabla \times \boldsymbol{A}_{f, n k} \\
& \nabla \cdot \boldsymbol{A}_{f, n k}=0 .
\end{aligned}
$$

但し， $\sigma$ : 二次導体の導電率 $(\mathrm{S} / \mathrm{m}), \mu:$ 二次導体の 透磁率 $(\mathrm{H} / \mathrm{m}), \boldsymbol{v}$ : 二次導体速度 $(\mathrm{m} / \mathrm{s})$

そこで，第 2 図で速度 $v_{2}(\mathrm{~m} / \mathrm{s})$ で走行中の二次導体 領域 IIIのベクトルポテンシャル $\boldsymbol{A}_{f, \pi k} \mathbb{k}^{\mathbb{I}}=\left(A_{x, f, \pi k^{\mathrm{I}}}\right.$, $\left.A_{y, f, n k}, 0\right)$ とエアギャップ領域 III のベクトルポテン シャル $\boldsymbol{A}_{f, n k}{ }^{\mathbb{I}}=\left(A_{x, r, n k}{ }^{\mathbb{I}}, A_{y, r, n k}, 0\right)$ Ф解は，モデルの 物理的性澌加ら一般㐸次の变数分離形で与えられる。

$$
\begin{aligned}
& A_{y, f, n k} \mathbb{I}=2 C_{f, n k} \mathbb{I} \cos \frac{\pi}{h_{2 k}} y \\
& \times \cosh K_{f, n k} \mathrm{I} z \cdot e^{j \frac{\pi}{\tau_{1 n}}\left(v_{1 n} t-x\right)} \\
& A_{y, f, n k} \mathbb{I}=\left(C_{f, n k} \mathbb{I I I} e^{K_{n k} z^{\mathbb{I}}}+D_{f, n k} \mathbb{I I} e^{-K_{n k} z \mathbb{I}}\right) \\
& \times \cos \frac{\pi}{h_{2, k}} y \cdot e^{j \frac{\pi}{\tau_{i n}}\left(v_{1 n} t-x\right)}
\end{aligned}
$$

但し，

$$
K_{f, n k} \mathbb{I}=\sqrt{\left(\frac{\pi}{\tau_{1 n}}\right)^{2}+\left(\frac{\pi}{h_{2 k}}\right)^{2}+j \sigma \mu s_{f n} v_{1 n} \frac{\pi}{\tau_{1 n}}}
$$




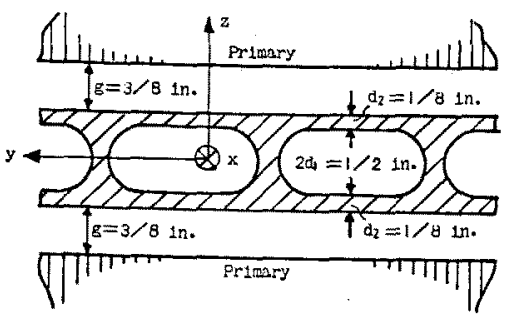

(a) 中空アルミニりム二次辡体

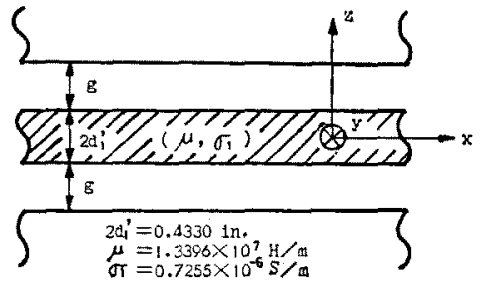

(b) 等価単一構造二次整体

第 3 図 中空アルミニウムリアクションレール とその等価二次導体

Fig. 3. Hollow aluminum reaction rail and tise quivalent secondary.

$$
K_{n k} \mathrm{mI}=\sqrt{\left(\frac{\pi}{\tau_{1 n}}\right)^{2}+\left(\frac{\pi}{h_{2 k}}\right)^{2}}
$$

$s_{f n}=\left(v_{1 n}-v_{2}\right) / v_{1 n}=1-(1-s) \tau / \tau_{1 n}:$ 前進波

第 $n$ 調波す心゙り

$s=\left(v_{1}-v_{2}\right) / v_{1}:$ すへり， $v_{1}=2 \tau f_{1}:$ 同期速度 $(\mathrm{m} / \mathrm{s})$

ここで， $A_{x, f, n k}$ II $A_{x, f, n k}$ は(11) 式し(12)，

式の関係から与えられる。

そこで，(12)，(13)式の末定定数 $C_{f, n k}$ ㅍ․ $C_{f, n k}$ II, $D_{f, n}$ "I は次の境界条件式加ら決定さ机る。

(1) 領域 II ट III の境界: $z=d$

$$
\begin{aligned}
& A_{y, f, n k} \text { II }=A_{y, f, n k} \text { II } \ldots \ldots \ldots . . . \\
& \frac{1}{\mu} \frac{\partial A_{y, f, n k} \text { II }}{\partial z}=\frac{1}{\mu_{0}} \frac{\partial A_{y, f, n k} \text { II }}{\partial z}
\end{aligned}
$$

（2）領域 III と N の境界： $z=d+g$ ここで, 頒域 IV の透磁率は繁限大，導電率は零とすれば次式 が成立する。

$$
\frac{1}{\mu_{0}} \frac{\partial A_{y, f, n k} \text { II }}{\partial z}=j_{1 y, f, n k}
$$

但し， $\mu_{0}: エ ア キ ゙ ャ ッ フ ゚ の$ 透磁率 $(\mathrm{H} / \mathrm{m})$

そこで，(17)～(19)式の境界㷊件から末定定数老決 定しすれば，領域 II と III のベクトルポテンシャル 汃次式のように求められる。

$$
A_{x, f, n k} \mathbb{\Pi}=j \mu_{0} \frac{\pi}{\tau_{1 n}} J_{1, f, n k} \frac{\pi}{h_{2 k}} H_{f, n k} \Pi(z)
$$

$$
\begin{aligned}
& \times \sin \frac{\pi}{h_{2 k}} y \cdot e^{j \frac{\pi}{\tau_{i n}}\left(y_{1 n} t-x\right)} \\
& A_{y, f, n k} \mathbb{I}=\mu_{0} J_{1, f, n k} H_{f, n k} \mathrm{I}(z) \cos \frac{\pi}{h_{2 k}} y \\
& X_{e^{j \frac{\pi}{\tau_{1 n}}}\left(v_{1 n} t-x\right)} \\
& A_{x, f, n k} \mathbb{I I}=j \mu_{0} \frac{\tau_{1 n}}{\pi} J_{1, f, n k} \frac{\pi}{h_{2 k}} H_{f, n k} \mathbb{I}(z) \\
& \times \sin \frac{\pi}{h_{2 k}} y \cdot e^{j \frac{\pi}{\tau_{1 n}}\left(v_{\left.1 n^{t}-x\right)}\right.} \\
& A_{y, f, n k^{\mathrm{II}}}=\mu_{0} J_{1, f, n k} H_{f, n k} \text { III }(z) \cos \frac{\pi}{h_{2 k}} y \\
& \times e^{j \frac{\pi}{\tau_{3 n}}\left(v_{1 n} t-x\right)}
\end{aligned}
$$

但し,

$$
H_{f, n k} \mathbb{I}(z)=\frac{\cosh }{\left\{\tanh K_{n k} \text { III } g+\frac{\mu_{0} K_{f, n k} \text { I }}{\mu K_{n k} \text { III }} \tanh \right.}
$$

$K_{f, n k} I z$

$K_{f, n k}$ II $\left.d\right\} \cosh K_{n k}$ II $g \cdot \cosh K_{f, n k}$ II $d$

$$
\begin{gathered}
H_{f, n k} \text { I }(z)=\frac{\left\{1+\frac{\mu_{0} K_{f, n k} \text { II }}{\mu K_{n k} \text { II }} \tanh K_{f, n k} \text { II } d\right.}{\left\{\tanh K_{n k} \text { III } g+\frac{\mu_{0} K_{f, n k} \text { II }}{\mu K_{n k} \text { II }}\right.} \\
\frac{\left.\tanh K_{n k} \text { III } g\right\} \cosh K_{n k} \text { I }(z-d)}{\left.\tanh K_{f, n k} \text { II } d\right\} \cosh K_{n k} \text { II } g} \ldots(25)
\end{gathered}
$$

領域 II と III $の ~ x$ 成分の後進波の第 $n k$ 調波の ベクトルポテンシャル $A_{x, b, n k}$ II $A_{x, b, n k}$ は $(20)$, (22) 式の両式で $\left(v_{1 n} t-x\right) \rightarrow\left(v_{1 n} t+x\right), j \mu_{0} \rightarrow-j \mu_{0}$,

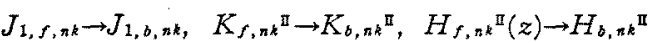
$(z), H_{f, n k}$ III $(z) \rightarrow H_{b, n k}$ III $(z)$ にそれぞれ置換して得ら れる。ここで, $H_{b, n k^{\mathbb{I}}}(z)$ ¿ $H_{b, n k} \mathbb{M}^{\mathbb{1}}(z)$ は (24), (25) 式の両式て $K_{f, n k} \mathbb{I} \rightarrow K_{b, n k}$ 江置換して得られる。

但し,

$$
\begin{array}{r}
K_{b, n k} \Pi=\sqrt{\left(\frac{\pi}{\tau_{1 n}}\right)^{2}+\left(\frac{\pi}{h_{2 k}}\right)^{2}+j \sigma \mu v_{1 n} s b \frac{\pi}{\tau_{1 n}}} \\
\ldots \ldots \ldots \ldots \ldots \ldots \ldots \ldots \ldots \ldots(26) \\
s_{b n}=1+(1-s) \tau / \tau_{1 n} \quad \ldots \ldots \ldots \ldots \ldots \ldots \ldots(27)
\end{array}
$$

また，領域 II ट III の $y$ 成分の後進波の第 $n k$ 調波のベクトルポテンシャル $A_{y, b, n}{ }^{\text {I }}$ と $A_{y, b, n k}$ は,

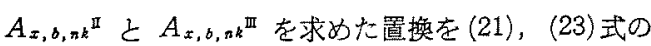
两式に適用して求められる。

そこで，(4)，(5)式の車式の一次表面電流によ。 て，一次鉄心表面上 $(z=d+g)$ において誘導される 
頒域 III のエアギャップ磁束密度の各成分 $B_{x 1}$ III, $B_{y 1}$ III， $B_{z 1}$ III，次式でそれぞれ与えられる。

$$
\begin{aligned}
& B_{x 1} \mathrm{~m}=\sum_{n=1}^{\infty} \sum_{k=1}^{\infty}\left[\left(-\frac{\partial A_{y, f, n k} \mathrm{~m}}{\partial z}\right)\right. \\
& \left. \pm\left(-\frac{\partial A_{y, b, n k} \text { II }}{\partial z}\right)\right]_{z=d+\theta}=-\mu_{0} j_{1 y} \ldots \\
& B_{y, 1} \mathbb{I I}=\sum_{n=1}^{\infty} \sum_{k=1}^{\infty}\left[\frac{\partial A_{x, f, n k} \text { II }}{\partial x}\right. \\
& \left. \pm \frac{\partial A_{x, b, n k} \mathbb{I}}{\partial x}\right]_{z=d+g}=\mu_{0} j_{1, x} \\
& B_{z 1} \text { III }=\sum_{n=1}^{\infty} \sum_{k=1}^{\infty}\left[\left(\frac{\partial A_{y, f, n k} \text { II }}{\partial x}-\frac{\partial A_{x, f, n k} \text { W }}{\partial y}\right)\right. \\
& \left. \pm\left(\frac{\partial A_{y, b, n k} \mathrm{~m}}{\partial x}-\frac{\partial A_{x, b, n k} \mathbb{W}}{\partial y}\right)\right]_{z=d+0} \\
& =-j \mu_{0} \sum_{n=1}^{\infty} \sum_{k=1}^{\infty} \frac{\tau_{1 n}}{\pi} K_{n k} \text { II } \cos \frac{\pi}{h_{2 k}} y \\
& \times\left\{-J_{1, f, n k} H_{f, n k} \mathbb{I I}(z) \cdot e^{j \frac{\pi}{\tau_{1 n}}\left(v_{1 n} t-x\right)}\right. \\
& \left. \pm J_{1, b, n k} H_{b, n k} \mathbb{I}(z) \cdot e^{j \frac{\pi}{\tau_{1 n}}\left(v_{1 n} t+x\right)}\right\} z=d+g
\end{aligned}
$$

但し, 複号：十：偶数極, 一：奇数極

〈3.2〉 リニアインダクションマシンの特性算定式 $z$ 成分の磁束密度の第 $n k$ 調波の前進波 $B_{z 1, f, n k}$ による一次誘導起電力 $E_{1, r, n k}(\mathrm{~V} / \mathrm{m})$ は,

$$
E_{1, f, n k}=v_{1 n} B_{z 1, f, n k} \text { II }
$$

従って，起磁力の横方向分布の幅 $h_{2}(\mathrm{~m})$ の実效直列 導体数 $2 k_{w n} k_{L_{p n}} N_{p h}$ 亿誘導される前進波の第 $n k$ 調 波の起電力の実効値 $\dot{E}_{1, f, n k}(\mathrm{~V})$ は,

$$
\begin{aligned}
\dot{E}_{1, f, n k}= & -\int_{-h_{2} / 2}^{h_{2} / 2} \frac{2}{\sqrt{2}} v_{1 n} k_{\omega n} k_{L p n} N_{p h} \\
& \times B_{z 1, f, n k} \mathbb{I I} d y \quad \ldots \ldots \ldots \ldots \ldots . . .
\end{aligned}
$$

これに対する供給電圧 $\dot{E}_{1, f, n k^{\prime}}=-\dot{E}_{1, f, n k}$ である 加ら，その等価二次インピーダンス $\dot{Z}_{1, f, n k}(\Omega)$ は

$$
\begin{aligned}
\dot{Z}_{1, f, n k} & =\dot{E}_{1, f, n k}{ }^{\prime} / I_{1} \\
& =r_{2 e, f, n k}+j x_{2 e, f, n k}
\end{aligned}
$$

後進波の等伍二次インピーダンス $Z_{1, b, n k}(\Omega)$ は

$$
\dot{Z}_{1, b, n k}=r_{2 e, b, n k}+j x_{2 e, b, n k}
$$

そこで，一次端子管压 $V_{1}(\mathrm{~V})$ ，一次抵抗 $r_{1}(\Omega)$ ，一 次リアクタンス $x_{1}(\Omega)$ 少与えられると，一次端子か ら見た全インピーダンス $Z_{t}(\Omega)$ は次式で与えられる。

$$
Z_{i}=\sqrt{\left(r_{1}+r_{2 e}\right)^{2}+\left(x_{1}+x_{2 e}\right)^{2}}
$$

但し，

$$
\begin{aligned}
& r_{2 e}=\sum_{n=1}^{\infty} \sum_{k=1}^{\infty}\left(r_{2 e, f, n k}+r_{2 e, b, n k}\right) \ldots \\
& x_{2 e}=\sum_{n=1}^{\infty} \sum_{k=1}^{\infty}\left(x_{2 e, f, n k}+x_{2 e, b, n k}\right)
\end{aligned}
$$

一次電流 $I_{1}(\mathrm{~A})$ は次式で求められる。

$$
I_{1}=V_{1} / Z_{t}
$$

$I_{1}$ が定まれば(28)〜(30)式の $B_{x 1}$ II", $B_{y 1}$ III,$B_{x 1}$ II は一次電流が決定される。そこで，推力 $F_{x}(\mathrm{~kg}) ， 二$ 次導体の横方向片㑡化作用する横方向垂直力 $F_{y}(\mathrm{~kg})$, 垂直力 $F_{2}(\mathrm{~kg})$ はマクスウェルの磁気応力テンソルの 概念を用いて婊示すれば，それぞれ次式のように書け る。

$$
\begin{aligned}
& F_{x}=\int_{-h_{2} / 2}^{h_{2} / 2} f_{x} d y . \\
& F_{y}=\int_{0}^{h_{z} / 2} f_{y} d y . \\
& F_{z}=\int_{-h_{z} / 2}^{h_{z} / 2} f_{z} d y .
\end{aligned}
$$

但し, $f_{x}(\mathrm{~kg} / \mathrm{m}), f_{y}(\mathrm{~kg} / \mathrm{m}), f_{z}(\mathrm{~kg} / \mathrm{m})$ は

$$
\begin{aligned}
f_{x}= & \int_{-L_{1} / 2}^{L_{1} / 2} \frac{1}{9.8}\left\{2 \times \frac{1}{2} \operatorname{Re}\left(\frac{1}{\mu_{0}} B_{z 1} \text { II } B_{x 1} \text { III } *\right)\right\} \\
& \times d x \ldots \ldots \ldots \ldots \ldots \ldots \ldots \ldots \ldots \ldots \ldots \ldots \ldots \ldots \ldots \ldots \ldots \ldots \ldots \ldots \ldots \ldots \\
f_{y}= & \int_{-L_{1} / 2}^{L_{1} / 2} \frac{1}{9.8}\left\{\frac{1}{2} \operatorname{Re}\left(\frac{1}{\mu_{0}} B_{z 1} \mathbb{I I} B_{y 1} \mathbb{I I} *\right)\right\} d x
\end{aligned}
$$

$$
\begin{aligned}
f_{z}= & \int_{-L_{j, 2} / 2}^{L_{2 / 2}} \frac{1}{9.8}\left\{\frac { 1 } { 2 } \operatorname { R e } \left(\frac{1}{2 \mu_{0}} B_{z 1} \mathbb{I} B_{z \mathbb{1}} \mathbb{I} *\right.\right. \\
& \left.\left.-\frac{1}{2 \mu_{0}} B_{x 1} \mathbb{I} \mathbb{I} B_{x 1} \mathbb{I} *-\frac{1}{2 \mu_{0}} B_{y 1} \mathbb{I} \mathbb{I} B_{y 1} \mathbb{I I} *\right)\right\} \\
& \times d x \quad \ldots \ldots \ldots \ldots \ldots \ldots \ldots \ldots \ldots(44)
\end{aligned}
$$

\section{4. リニアインダクションマシンの特性}

実験機として，低速機は文献（1）と同じものを用 い，高速機の数值例としてアメリカ運輸省の浮上試験 車 Tracked Levitated Research Vehicle (TLRV)(2) (6)を用いる。第 3 図 (a) (b) にTLRV の中空了ル ミニゥムリアクションレールとその等価単一二次導体 を示し，(b)図の $2 d_{1^{\prime}}$ 之 $\sigma_{1}, \mu$ の数值は文献 (7) に上って算出した。磁束密度, 推力, 垂直力の縦方向 分布については多くの報告(1) (3)(8)(9)があるので, 本論 文ではこ机らの横方向分布を定電流運転時の屯とで詳 述する。

$\langle 4.1\rangle$ 低速機の特性 低速機の特性計算は。台形 形とコイル端部起磁力の形状が $(1-\sin \theta)$ 形 $^{(5)}$ の二と おりの三次元解析と二次元解析による。

第 4 図 第 11 図任定電流運転時の磁束密度, 推力, 横方向垂直力，垂直力の各横方向分布を示し，図の左 側偟台形形，右側以 $(1-\sin \theta)$ 形を示した。計算は $I_{1}=6.85 \mathrm{~A}, f_{1}=60 \mathrm{~Hz}, x=0, z=15 \mathrm{~mm}$ の位置で 


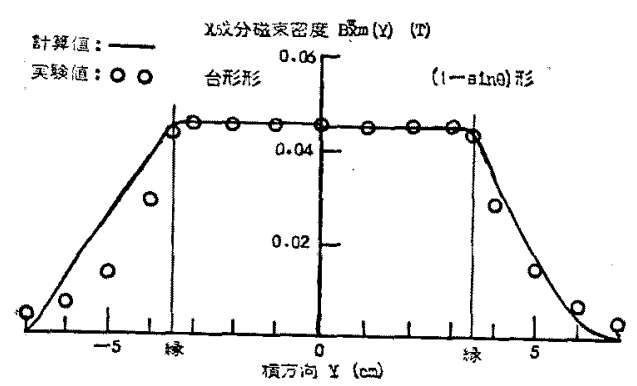

台形形已 $(1-\sin \theta)$ 形の誈十算俌上実駼值

第 4 図 $x$ 成分磁束密度の空間分布

Fig. 4. Space distribution of the $x$-component Hux density.

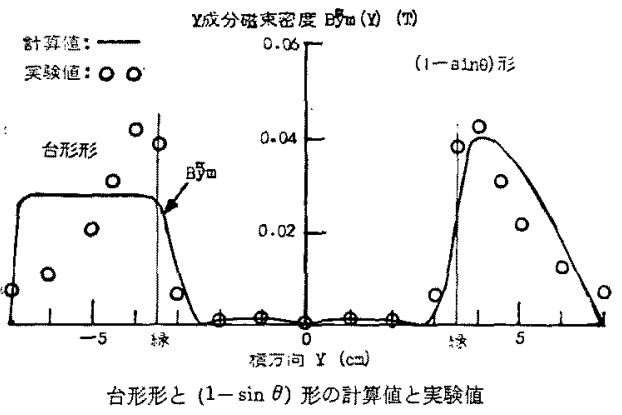

第 5 図 $y$ 成分磁束密度の空間分布

Fig. 5. Space distribution of the $y$-component flux density.

行なった。

第4 図〜第6 図任磁束密度の $x, y ， z$ の各成分の

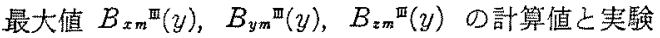
值を示す。これらの値は，コイル端部では計算值が寒 駼值より若干大きい。これは，コイル端部まで一次鉄 心があると仮定した解析のためである。

第7図の $f_{x}(y)$ 酒雨形の計算值とあほとんど同形 になり、コイル端部に战いても推力加ある分布とな る。第 8 図の $f_{y}(y)$ はコイル端部分で反発力分布と なり，一次鉄心横方问緣部で最大值走し，ての力は 二次導体が一次鉄心対して対称に位置する場合は相 互に打消し合って現象として現われない。

第 9 図の $f_{x}(y)$ は両形と6一次鉄心表面では平 たん分布になり，縁部で最大值を示し，一次巻線のコ イル端部まで一次鉄心が苛ると仮定しているに李拘ら ず，その両端に向って急激に減少して反発力分布之な ることが認められる。

第 10 図认定電流運転時の $F_{x}, F_{y}, F_{z}$ の三次元解 析値之二次解析值之実測値の速度特性を示す。 $F_{x}$ の 両形の三次元解析値は二次元解析値上り若干大きい值 を示す。これは第 7 図で明らかなように， $f_{x}(y)$ のコ

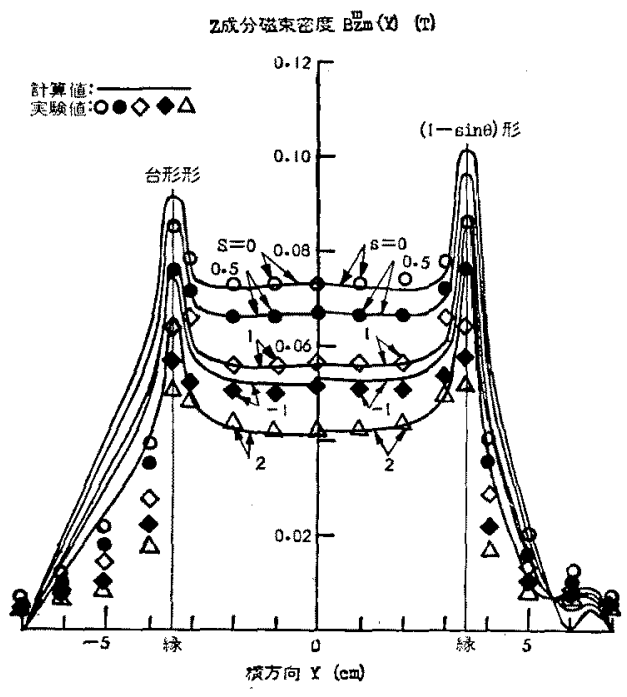

台形形と $(1-\sin \theta)$ 形の計算犆と塞験嚾

第 6 図 $z$ 成分磁束密度の空間分布

Fig. 6. Space distribution of the $z$-component flux density.

イル端部の分布が鉄心を仮定しているため正推力とな っていることに起因する。 $F_{y}$ は第 8 図 $f_{y}(y)$ の分 布より，すべりに無関係に反発力上なり、 $s=0$ 近傍で 最大となる。

これは実測が困難であるので三次元解析值だけを示

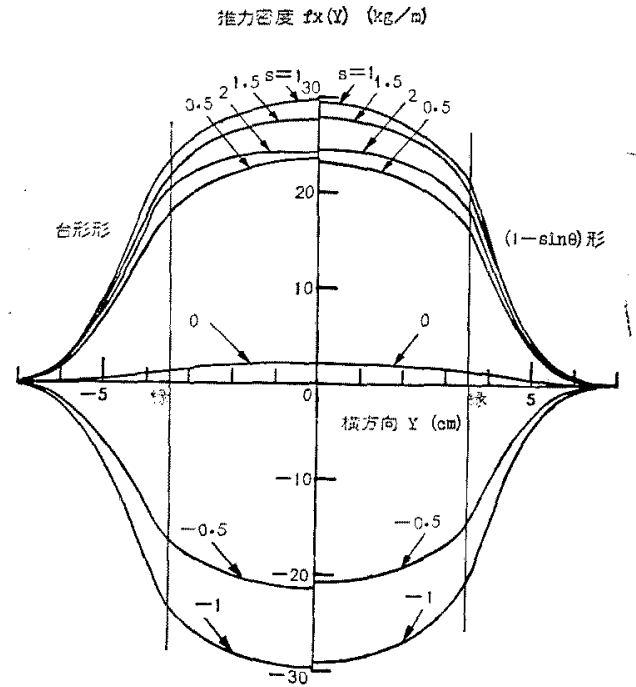

台形形己 $(1-\sin \theta)$ 形《よる暗算值

第 7 図 推力の空間分布

Fig. 7. Spase distribution of the thrust. 


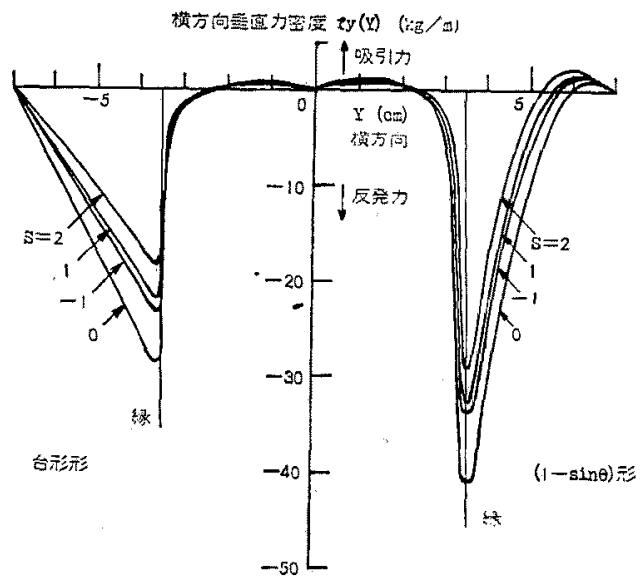

台形形と $(1-\sin \theta)$ 形による訢算值

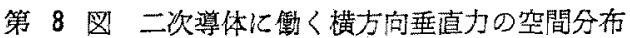

Fig. 8. Space distribution of the transverse vetical force acting on the secondary member.

した。 F、は逆相制動では三次元解析値が二次元解析 值より小さく，電動機動作之発電機動作では大きい。 てれは第 9 図 $f_{\mathrm{z}}(y)$ のイル端部の負垂直力分布の 影響が逆相制動で大きく，他の動作では小さいことに よると考えられる。

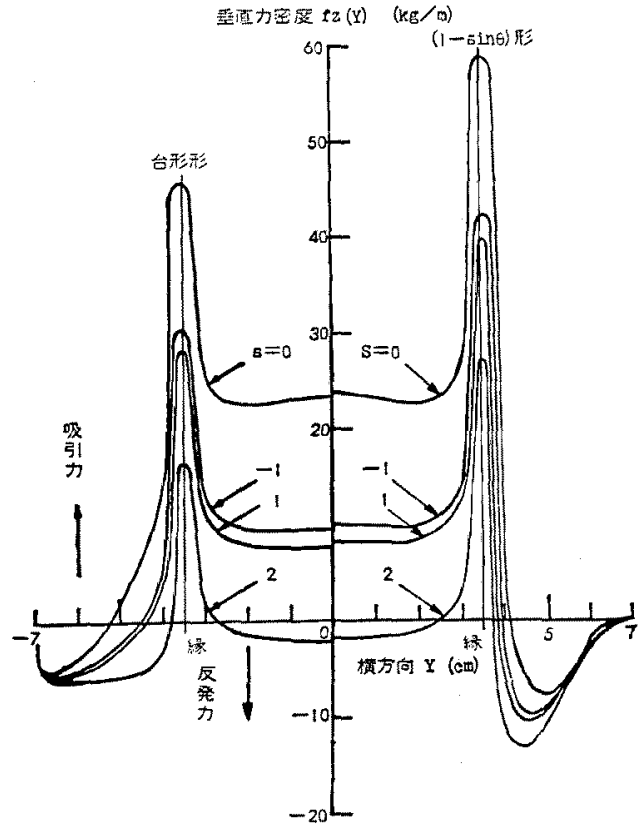

台形形と $(1-\sin \theta)$ 形飞上る郡算值

第 9 図一次鉄心儌く垂直力の空間分布

Fig. 9. Space distribution of the vertical force acting on the primary member.

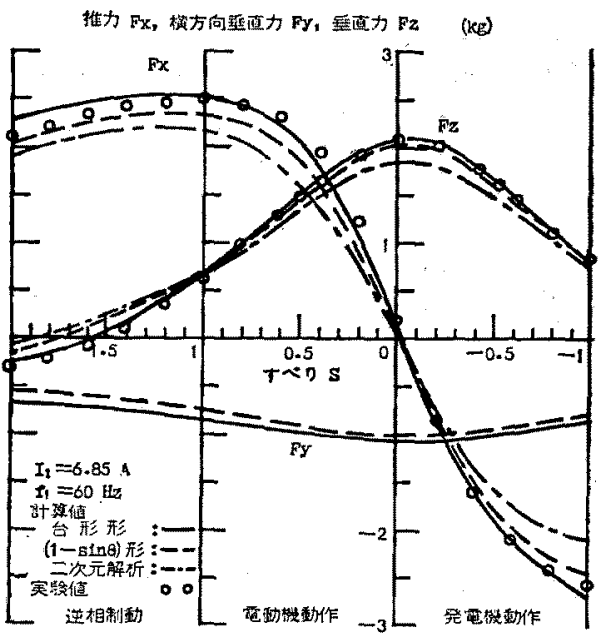

第 10 図定電流軍転による推力, 横方向垂直力, 垂直力-速度特性

Fig. 10. Thrust, transverse vertical force and vertical force-slip characteristics under constant current drive.

第 11 図纪定電圧運転時の $F_{x}, F_{y}, F_{z}$ の速度特性 を示す。本三次元解析に用いた一次インピーダンスは 二次元解析に用いた値を使用している。本来，一次コ イル端部に起磁力を考虑すれば，その一次リアクタン スは二次元解析に用いたものより小さい值となる。そ れゆ元本三次元解析に二次元解析の一次リアクタンス

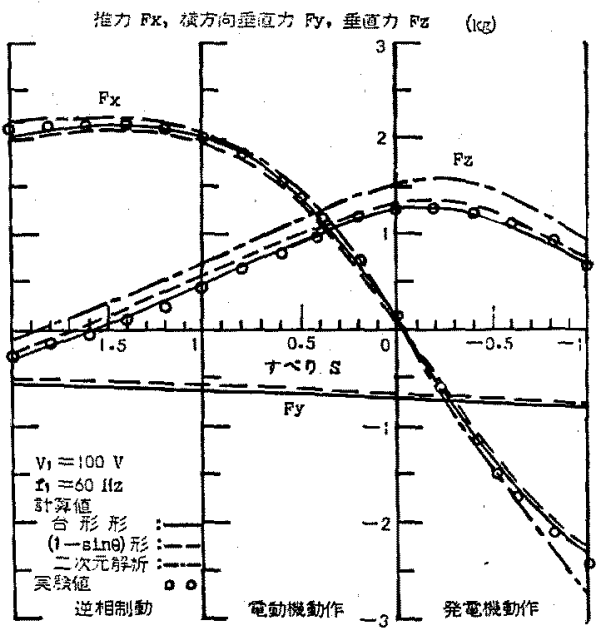

第 11 図 定電压計転汇よる推力，横方向垂苴方， 垂直力-速度特性

Fig. 11. Thrust, transverse vertical force and vertical force-slip characteristics under constant voltage drive. 


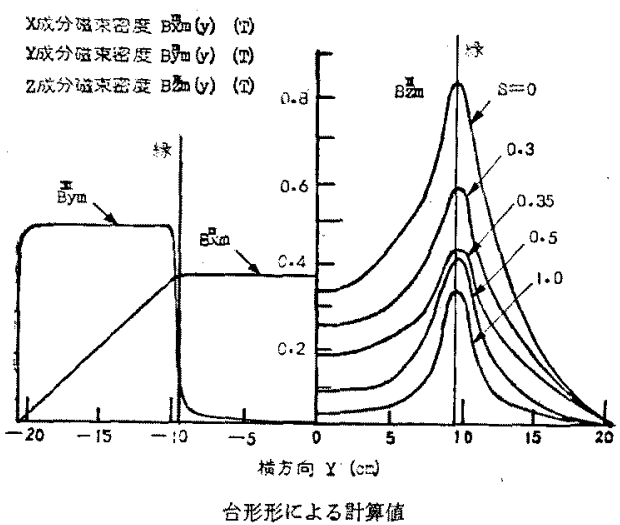

第 12 図 $x, y, z$ の各成分磁束密度の空間分布

Fig. 12. Space distribution of the $x, y$ and $z$-components flux density.

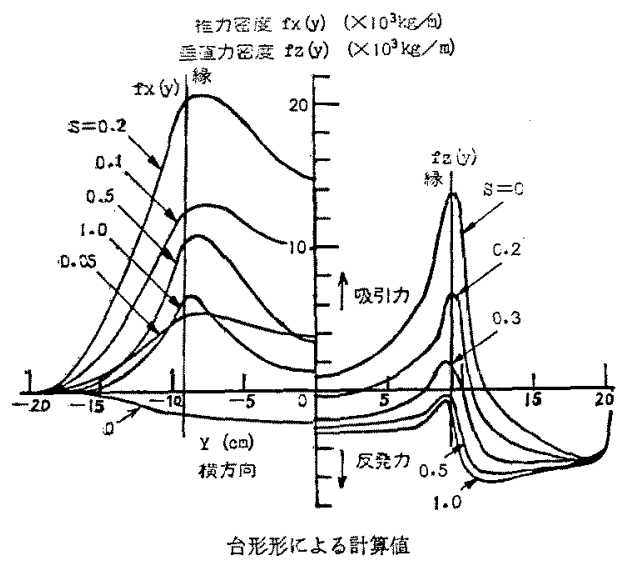

第 13 図 推力之垂直力の空間分布

Fig. 13. Space distribution of the thrust and vertical force.

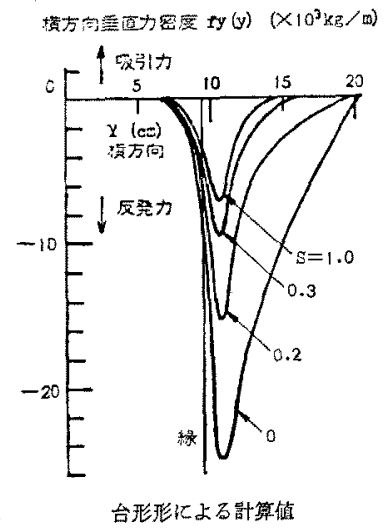

第 14 図 二次導体に勳く横方向垂直力の空間分布 Fig. 14. Space distribution of the transverse vertical force acting on the secondary member.

昭 $54-11$
を用いれば，てれが二重評価されて全インピーダンス を大きくし，一次電流を小さくする。そこで第 11 図 の $F_{x} ， F_{y} ， F_{z}$ は，すべて二次元解析值上り三次元解 析值が小さな值を示すこととなる。以上から低速譏の 推力, 垂直力の二次元解析值上三次元解析值付若干の 差異はあるが，実験值とあまり变わらないとと，また 垂直力, 横方向垂直力の横方向分布はコイル端部分で それぞれ反発力分布となることが認められた。

〈4-2〉高速機の特性高速機では台形形三次元 解析之二次元解析で $I_{1}=914 \mathrm{~A}, f_{1}=165 \mathrm{~Hz}, x=0$, $z=4.763 \mathrm{~mm}$ の位置で計算し，乙れらの值を電動機 動作領域で比較検討する。まず，定電流運転時の三次 元解析汇よる一次鉄心表面上の磁束密度の横方向分布 について述べる。第 12 因の左側に $B_{x m} \mathrm{~m}(y)$ 之 $B_{y m} \mathrm{~m}(y)$ を右側化 $B_{z m} \mathrm{~m}(y)$ を示す。 $B_{x m} \mathrm{I}(y)$ と $B_{y m} \mathrm{~m}(y)$ は，低速機の第 4 图之第 5 図の台形形と全く

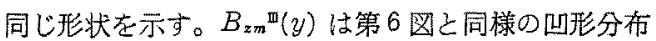
となるが，その凹形は深くなっていることが認められ

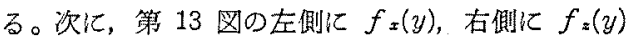
を示す。 $f_{x}(y)$ は，低速領域ては一次鉄心雨縁部で最 大推力を生じ，同期速度で負推力分布になる。 $f:(y)$ は，高速領域では吸引力分布となることが認められ る。第 14 図任 $f_{y}(y)$ を示す。乙れは高速領域で急 激に大きくなることが認められる。

第 15 図汇定電流運転時の $F_{x}, F_{y}, F_{x}$ ，第 16 図 亿定電壬運転時の $F_{x}, F_{y} ， F_{z}$ のそれぞれの速度特性 を示す。 $F_{x}$ 蛙定電流運転では三次元解析值が二次元 解析値より若干大きく，定電圧運転では若干小さいこ とが認められる。これは低速機の各運転時の場合之同

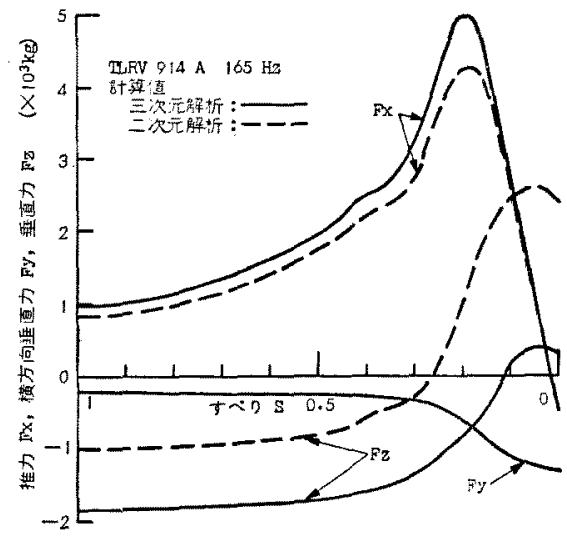

第 15 図定電流運軽に上る推力，横方向垂直力， 垂直力-速度特性

Fig. 15. Thrust, transverse vertical force and vertical force-slip characteristics under constant current drive. 


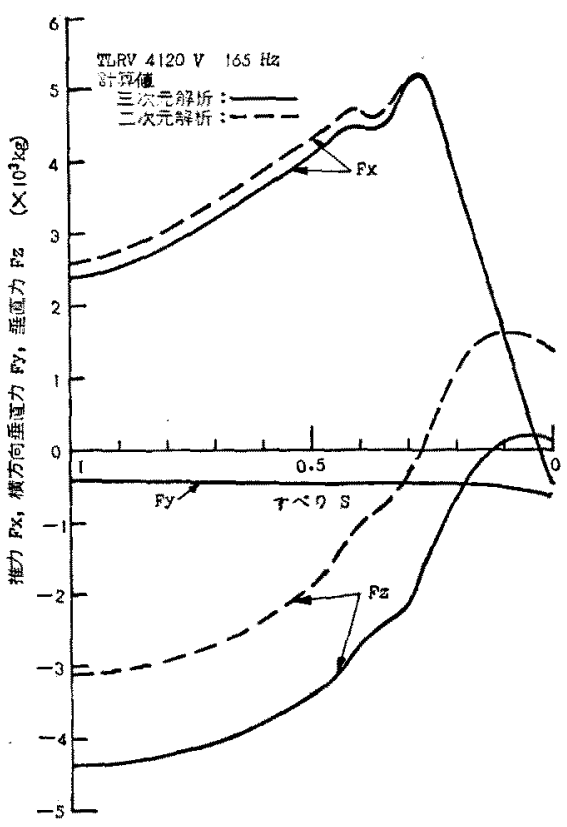

第 16 図 定電王運転による推力，横方向 垂直力, 垂直力一速度特性

Fig. 16. Thrust, transverse vertical force and vertical force-slip characteristics under constant voltage drive.

じ理由で競明できる。また，いずれの運転時と屯高速 通常運転領域で $F_{x}$ の雨解析結果はほほ一致してい る。 $F_{y}$ は低速機之同様に反発力となり，定電流運転 では $s=0$ で最大值を示すが，定電圧計転では定電流 運転に比へておまり大きくなく，すべりに反比例して 僅かな增加を示している。 $F_{x}$ の呧速領域の三次元解 析値は定電流運転で二次元解析值の約 2 倍の反発力を 示し，定電圧運転では約 1.4 倍の反発力を示してい る。また，高速領域で，耐運転時之李二次元解析值 に比べて非常に小さな吸引力となるととが認められ る。これらの差異は，三次元解析による直力の (44) 式の右边の第 3 項のコイル端部の $B_{y 1}$ III影響による あのと考えられる。

\section{5. あとがき}

（1）推力の横方向分布は低速機之高速機では相当 に異なる。本三次元解析ではコイル端部の推力が計算
されるなめ二次元解析より大きい值を示すししかし， その差異はあまり大きくないので，推力の解析は低速 僟，高速機之屯二次元解析 ${ }^{(2)}$ で十分である。

（2）垂直力の横方向分布では，一次コイル端部分 を含りて一次鉄心加あると仮定しているのにもかかか らず，その端部ですべりに無関保化反発力分布之なる こ之を示し，乙の影響は低速機ではあまり認められな いが，高速機では特に始動時近傍で二次元解析值よD 比较で相当大きな反発力となること，通常運転される すべりの近傍では，二次元解析值より割合小さい值の 吸引力になることが認められた。

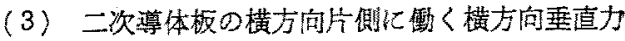
はすべりに無関係儿反発力となる。定電阯運転ではす ベりに対してその值はあまり変らないが，定電流運檕 ではその值か高速領域で急激化增加し， $s=0$ の近傍で 最大值を示すとよ加ら，二次導体板の横方向の瘖位に 上る横方向烡直力の影響を高速機では考虑する必要が ある。

以上，本三次元解析で LIM の支持案内影響を及 ぼす垂直力，横方向俥㨁力をより詳しく解明できるて さを示した。

䅂りに，本研究に御協力頂いた九州大学大学院生小 川幸吉, 宮崎大学大学院生黒木 厚両氏之同大学技官 白坂俊一，原田忠男の雨氏に樑く感謝する。

(昭和53年 7 月31日受付，同54年 5 月 22 日再受付)

\section{文献}

（1）梅律・野中：「低䢟りニアインダクションマシンの特性」電 学諭 B 97, 15 (明 52-1)

(2) E. R. Laithwaite Motors Using a Space Harmonic Technique fS. Nonaka \& K. Yoshida)". Transport Without Wheels, 187 216, Elek Science, London (1977)

(3) E. R. Laithwaite 編: "Three-Dimensional Analysis of the Linear Motor (K. Obertetl)" ibid., 217 247 (1977)

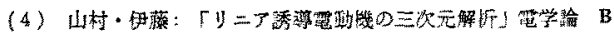
96-155 (埅 51-3)

(5) T.W. Preston \& A.B.J. Reece: "Transverse edge effect in linear motors" Proc. Instn. Elect. Engrs. 116. 6, $973(1969-6)$

(6) J.H. Dannan, R.N. Day \& G.P. Kalman: "A Linear Induction Motor Propulsion System for High-Speed Ground Vehicles" Proc. IEEE 61, 5, 621 (1973)

（7）野中・幸山：「中空アルミニクムりアクションレールさ等洒

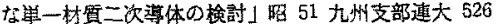

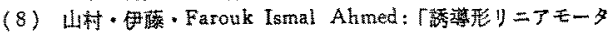

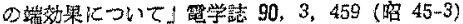

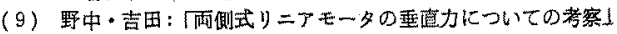
雷学噼 B 93471 (昭 48-10) 